DOI: 10.33766/2524-0323.93.285-296

УДК 343.14:336.228.34

Моргун Н. С., кандидат юридичних наук, професор кафредри економічної безпеки та фінансових розслідувань Нащіональної академії внутрішніх справ (м. Киї, Україна) e-mail: morgun.nadiy@gmail.com ORCID iD: https:/ / orcid.org/ 0000-0002-2997-9975

Терещенко Ю. В., кандидат юридичних наук, доцент, професор кафедри кримінального процесу Національної академії Внутрішніх справ (м. Киї, Україна) e-mail: vladysikter@ukr.net ORCID iD: https:/ / orcid.org/0000-0002-5353-0887

\title{
ОБСТАВИНИ, ЩО ПІДЛЯГАЮТЬ ДОКАЗУВАННЮ ПІД ЧАС РОЗСЛІДУВАННЯ УМИСНОГО УХИЛЕННЯ ВІД СПЛАТИ ПОДАТКІВ, ЗБОРІВ (ОБОВ'ЯЗКОВИХ ПЛАТЕЖІВ)
}

Стаття присвячена визначенню обставин, які підлягають доказуванню під час розслідування умисного ухилення від сплати податків, зборів (обов' язкових платежів), та їх допустимість під час судового розгляду. Наведено низку факторів, як об'єктивного, так і суб' єктивного характеру, що впливають на ефективність доказування обставин, визначених у частині 1 статті 91 КПК України, під час розслідування злочину, передбаченого статтею 212 КК України, та запропоновано можливі напрями їх вирішення. Виділено низку істотних обставин, які підлягають доказуванню, з огляду на специфічність аналізованого злочину.

Ключові слова: кримінальне провадження, ухилення від сплати податків, зборів (обов' язкових платежів), обставини, які підлягають доказуванню, допустимість доказів, судовий розгляд, вирок суду.

Постановка проблеми. На сьогодні кримінальні правопорушення у сфері господарської діяльності поряд із корупційними є чи ненаймасштабнішими та найнебезпечнішими правопорушеннями, які вагомо впливають як на надходження коштів до державного та місцевих бюджетів України, так і загалом на суспільне життя кожної людини та держави. Особливо серед усіх них виявляється такий злочин, як ухилення від сплати податків, зборів (обов' язкових платежів).

Задля відображення дійсної ситуації розслідування злочинів, передбачених статтею 212 Кримінального кодексу (КК) України, яка склалась на сьогодні, звернемося до статистичних показників Офісу Генерального прокурора. Так, згідно зі звітом цього органу, за січень-грудень 2018 року маємо такі показники: обліковано 1099 кримінальних правопорушень, закрито 256 кримінальних проваджень, з яких - 253 - за пунктами 1, 2, 4, 6 частини 1 статті 284 Кримінального процесуального кодексу (КТК) України; направлено до суду 39 обвинувальних актів; за січень-грудень 2019 року: обліковано 852 кримінальних правопорушень, закрито 298 кримінальних проваджень, 3 яких 291 - за пунктами 1, 2, 4, 6 частини 1 статті 284 КПК України; направлено до суду 22 обвинувальних акти; за січень-грудень 2020 року: обліковано 910 кримінальних правопорушень, закрито 124 кримінальних проваджень, 3 яких 123 - за 
пунктами 1, 2, 4, 6 частини 1 статті 284 КПК України; направлено до суду 10 обвинувальних актів [1].

Отже, статистичні показники далеко не завжди вказують на ефективність роботи органів, що здійснюють контроль за додержанням податкового законодавства. Саме це і стало ключовою причиною створення нового органу в державі, який буде спеціалізуватися на запобіганні, виявленні, припиненні й розслідуванні злочинів в економічній та фінансовій сферах.

28 січня 2021 року Верховна Рада України прийняла в другому читанні і в цілому проект Закону «Про Бюро економічної безпеки України» від 02.07.2020 № 3087-д, який передбачає створення в Україні зазначеного правоохоронного органу [2].

Для покращення ситуації, яка наразі склалася, органам, що здійснюють контроль за додержанням податкового законодавства, потрібно особливу увагу звертати на обставини, які підлягають доказуванню під час розслідування умисного ухилення від сплати податків, зборів (обов' язкових платежів).

Аналіз останніх досліджень і публікацій. Окремі аспекти доказування під час розслідування ухилення від сплати податків, зборів та інших обов' язкових платежів були висвітленні в наукових працях таких учених, як Л. П. Брич, Д. І. Голосніченко, О. А. Марущак, О. П. Мілевський, Н. А. Потомська, Г. Г. Філоненко, Г. Л. Чигрина та інших. Однак потребують свого більш грунтовного розгляду процесуальні аспекти щодо повноти дослідження обставин, які підлягають доказуванню під час розслідування умисного ухилення від сплати податків, зборів (обов'язкових платежів) відповідно до КПК України та аналізу судових рішень за результатами розгляду цих матеріалів кримінальних проваджень.

Формулювання цілей. Мета статті полягає у визначенні кола обставин, які підлягають доказуванню під час розслідування умисного ухилення від сплати податків, зборів (обов' язкових платежів), на підставі аналізу судових рішень. Задля досягнення вказаної мети слід вирішити такі завдання: охарактеризувати ті обставини, що можуть підлягати доказуванню під час розслідування ухилення від сплати податків, зборів (обов' язкових платежів); проаналізувати судові вироки за період з 2017 по 2020 роки і на їх основі виокремити низку обставин, які піллягають доказуванню під час розслідування зазначеного злочину.

Виклад основного матеріалу. Відповідно до частини 2 статті 91 КПК України, доказування полягає у збиранні, перевірці та ощінщі доказів 3 метою встановлення обставин, що мають значення для кримінального провадження [3].

Досліджуючи ці елементи процесу доказування, О. В. Пчеліна зазначила, що доказування в рамках кримінального провадження низки обставин у своїй сукупності дозволяють наступне: встановити наявність кримінального караного суспільно небезпечного діяння; визначити наявність в ознаках вчиненого діяння складу кримінального правопорушення; забезпечити відшкодування збитків, завданих злочином, та інших затрат, які пов'язані із провадженням досудового розслідування; обрати вид і міру покарання; поновити порушені кримінальним протиправним діянням права постраждалих осіб; попередити вчинення інших кримінальних правопорушень [4, с. 187]. 
Відповідно до частини 1 статті 91 КПК України, у кримінальному провадженні підлягають доказуванню:

1) подія кримінального правопорушення (час, місце, спосіб та інші обставини вчинення кримінального правопорушення); 2) винуватість обвинуваченого у вчиненні кримінального правопорушення, форма вини, мотив і мета вчинення кримінального правопорушення; 3) вид і розмір шкоди, завданої кримінальним правопорушенням, а також розмір процесуальних витрат; 4) обставини, які впливають на ступінь тяжкості вчиненого кримінального правопорушення, характеризують особу обвинуваченого, обтяжують чи пом'якшують покарання, які виключають кримінальну відповідальність або є підставою закриття кримінального провадження; 5) обставини, що є підставою для звільнення від кримінальної відповідальності або покарання; 6) обставини, які підтверджують, що гроші, цінності та інше майно, які підлягають спеціальній конфіскації, одержані внаслідок вчинення кримінального правопорушення та/або є доходами від такого майна, або призначалися (використовувалися) для схиляння особи до вчинення кримінального правопорушення, фінансування та/або матеріального забезпечення кримінального правопорушення чи винагороди за його вчинення, або $є$ предметом кримінального правопорушення, у тому числі пов' язаного з їх незаконним обігом, або підшукані, виготовлені, пристосовані або використані як засоби чи знаряддя вчинення кримінального правопорушення; 7) обставини, що є підставою для застосування до юридичних осіб заходів кримінально-правового характеру [3].

У частині 1 статті 94 КПК України передбачено, що слідчий, прокурор, слідчий судля, суд за своїм внутрішнім переконанням, яке грунтується на всебічному, повному й неупередженому дослідженні всіх обставин кримінального провадження, керуючись законом, ощінюють кожний доказ із точки зору належності, допустимості, достовірності, а сукупність зібраних доказів - 3 точки зору достатності та взаємозв' язку для прийняття відповідного процесуального рішення. Своєю чергою, у частині 1 статті 89 цього Кодексу вказано, що саме суд вирішує питання допустимості доказів під час їх оцінки в нарадчій кімнаті в процесі ухвалення судового рішення [3]. Іншими словами, ті докази, які оцінюють уповноважені суб'єкти на стадії досудового розслідування, ще не носять характеру остаточно допустимих під час розгляду матеріалів у судовому провадженні та ухваленні судового рішення.

Наведене пояснює, що саме суд, як слушно зазначають В. Г. Дрозд та С. Є. Абламський, відіграє вирішальну роль у визначенні допустимості доказів, ухвалює відповідне рішення на підставі оцінки допустимості, достовірності, достатності та належності доказів, які надали йому сторони на підтвердження своїх правових позищій. У цьому ракурсі суд має брати до уваги загальновизнані в доктрині кримінального процесу критерії допустимості доказів, а саме: 1) дотримання процесуальної форми отриманих доказів; 2) збирання доказів належним суб'єктом кримінального процесу; 3) належне джерело отримання доказів; 4) належний спосіб отримання доказів [5, с. 152].

Погоджуючись із тим, що суд відіграє вирішальну роль у визначенні допустимості доказів, проаналізуємо судові вироки судів України і визначимо обставини, 
які підлягають доказуванню під час розслідування ухилення від сплати податків, зборів (обов' язкових платежів).

Розглянемо вирок Деснянського районного суду міста Чернігова (провадження №1-кп/750/36/19) від 09.12.2019. Обвинувачення доводило, що особа (далі - обвинувачений), будучи директором ТОВ «ЛП ПЕК», отримала від осіб первинні бухгалтерські документи, у яких зафіксовані дані про нібито придбання службовими особами ТОВ «ЛП ПЕК» певного товару у ПСП «Огульчанське», ФГ «Крокос» та ТОВ «Ла-Пас», які мають ознаки фіктивності, після чого відобразила ці дані в податкових накладних [6].

У судовому провадженні судом було допитано шість свідків, показання яких полягали в тому, що частина з них не знали, що вони були директорами вищезазначених суб'єктів господарювання, а інша частина, яка була їх родичами чи знайомими, також не володіла такою інформацією. Бухгалтер ТОВ «ЛП ПЕК» зазначила, що працювала тільки 3 документами і не бачила товару, який надходив до підприємства, та стверджувала, що спеціальних приміщень чи техніки в підприємства не було ні у власності, ні в оренді [6].

Зі сторони обвинувачення суду було також надано низку письмових доказів. На наш погляд, найбілыш показовими серед них були: договори, які вказували на купівлю ТОВ «ЛП ПЕК» у згаданих суб'єктів господарювання товару із підписами директорів цих підприємств; податкові і видаткові накладні, що підписані директорами підприємств, а також товарно-транспортні накладні; акти звіряння взаємних рахунків вказаних суб'єктів господарювання, де у підприємствах, які продавали товар, були заборгованості; висновки судово-почеркознавчих експертиз, якими встановлено, що підписи, які ставилися представниками ПСП «Огульчанське», ФГ «Крокос» та ТОВ «Ла-Пас» у договорах поставки, специфікаціях, рахунках на оплату, податкових, видаткових та товарно-транспортних накладних до цих договорів виконані іншими особами з наслідуванням дійсних підписів представників вказаних підприємств; акти про результати документальної позапланової невиїзної перевірки ТОВ «ЛП ПЕК», якими встановлено: заниження сум податку на додану вартість (далі - ПДВ), завищення значення від' ємного значення на певну суму ПДВ; висновки судово-економічної експертизи, якими підтверджено заниження ТОВ «ЛП ПЕК» податку на додану вартість, яка підлягає нарахуванню та сплаті в бюджет; протоколи огляду нежитлових приміщень підприємств; протокол обшуку кабінету бухгалтера ТОВ «ЛП ПЕК», у ході огляду якого було вилучено вищезгадані документи [6].

Дослідивши вказані докази, суд виніс обвинувальний вирок за вчинення злочинів, передбачених частиною 3 статті 212, частиною 1 статті 366 КК України. 3i змісту судового рішення вбачається, що судом не було визнано якийсь доказ зі сторони обвинувачення недопустимим, тому всі докази були як допустимими, так і належними.

Відповідно до постанови Пленуму Верховного Суду України «Про деякі питання застосування законодавства про відповідальність за ухилення від сплати податків, зборів, інших обов'язкових платежів» від 08.10.2004 № 15, «За змістом статті 212 КК України відповідальність за ухилення від сплати податків, зборів, інших 
обов'язкових платежів, що входять у систему оподаткування, введені в установленому законом порядку і зараховуються до бюджетів чи державних цільових фондів, настає лише в разі, коли це діяння вчинено умисно. Мотив для кваліфікації останнього значення не має» [7].

Сукупність указаних доказів за розглядуваним судовим рішенням засвідчує, що обвинувачений мав прямий умисел на несплату в установлений строк податків, адже, зокрема, актами про результати документальної позапланової невиїзної перевірки ТОВ «ЛП ПЕК» встановлено, що було заниження сум податку на додану вартість та завищення значення від'ємного значення на певну суму ПДВ тощо. Це підтверджують і висновки судово-економічної експертизи. Значно підсилює доказову базу сторони обвинувачення й фіктивність суб'єктів господарювання, з якими обвинувачений укладав договори.

Як слушно зауважила А. М. Падалка, під час вирішення питання про кримінальну відповідальність за статтею 212 КК України має бути доведено не сам факт несплати у встановлений строк податків, зборів, інших обов' язкових платежів, а те, що здійснено умисне ухилення від їх сплати [8, с. 143].

Звернемо увагу також на вирок Шевченківського районного суду міста Києва від 08.10.2020 за № 1-кп/761/91/2020, у рамках якого прокуратура підтримувала обвинувачення за частиною 2 статті 212 КК України. Його зміст полягав у наступному: «Обвинувачена особа, будучи директором ТОВ «Аспекс» (далі - обвинувачений № 1), отримала від певних осіб первинні бухгалтерські та податкові документи фіктивного підприємства ТОВ «Онбоард». Після чого обвинувачений № 1 створював документальну видимість здійснення реальних господарських операцій за адресою ТОВ «Аспекс» від зазначеного фіктивного підприємства. Також обвинувачений № 1 використав реквізити завідомо неправдивих первинних фінансово-господарських документів під час складання бухгалтерського обліку та податкової звітності ТОВ «Аспекс» [9].

Задля підтвердження факту вчинення злочину, передбаченого частиною 2 статті 212 КК України, органи досудового розслідування надали низку процесуальних документів, серед яких: рапорти співробітників оперативних підрозділів, протоколи слідчих (розшукових) дій (обшуку приміщень, огляду документів, допитів тощо), негласних слідчих розшукових дій, акти перевірок, висновки експертів, видаткові накладні за певний період, показання свідків та інше. Своєю чергою, сторона захисту подала суду докази для обгрунтування невинуватості у вчиненні інкримінованого обвинуваченому злочину, а саме: журнал-ордер, картки рахунку, платіжні доручення, транспортні накладні, акти прийому-передачі тощо. Крім цього, за клопотанням обвинуваченого було допитано низку свідків [9].

Дослідивши надані сторонами докази, суд встановив наступне:

- на підтвердження виконання умов договору стороною захисту доведено дійсність угоди;

- в описовій частині акту перевірки про результати документальної позапланової невиїзної перевірки ТОВ «Аспекс» податковим інспектором визначається, що угода між ТОВ «Аспекс» і ТОВ «Онбоард» $є$ нікчемною через відсутність у ТОВ «Он- 
боард» адміністративно-господарських можливостей для виконання господарських зобов'язань по поставці товарів (робіт, послуг) та відсутність фактичних дій, спрямованих на виконання взятих на себе зобов' язань, але таке твердження посадової особи нічим не підтверджувалось;

- факт нікчемності правочинів, відповідно до законодавства України, визначає тільки суд (про це свідчать постанови Верховного Суду);

- у висновках судових експертів стверджується, що висновки документальної позапланової невиїзної перевірки ТОВ «Аспекс» 3 питань дотримання вимог податкового законодавства по взаємовідносинах з ТОВ «Онбоард» підтверджуються за умов, що органом досудового розслідування встановлено факт відсутності реальних господарських операцій. Недійсність (безтоварність) операцій з придбання ТОВ «Аспекс» товарів (робіт, послуг) у ТОВ «Онбоард», не знайшла підтвердження під час судового розгляду;

- аналіз доказів по справі в їх логічній сукупності вказує на те, що між зазначеними суб'єктами господарювання мали місце фінансово-господарські відносини.

- допитані судом свідки, як зі сторони обвинувачення, так і зі сторони захисту, підтверджують факт фінансово-господарських відносин між згаданими суб' єктами господарювання;

- надані прокурором диски та протоколи про результати проведення негласної слідчої (розшукової) дії не містять будь-яких фактичних даних про протиправні діяння обвинуваченого в цьому кримінальному провадженні;

- подані суду диски взагалі були не упаковані, знаходились в одному прозорому файлі формату А-4, що ставить під сумнів належне виготовлення та збереження вказаних носіїв інформації під час розслідування, відсутність доступу до них сторонніх осіб після їх запису та складення протоколів;

- у судовому засіданні сторона обвинувачення не надала доказів на спростування пояснень обвинуваченого [9].

Оцінивши в сукупності зібрані в кримінальному проваджені докази, суд вказав, що стороною обвинувачення поза розумним сумнівом не доведено наявність в обвинуваченого № 1 прямого умислу на вчинення інкримінованого йому кримінального правопорушення, а тому дійшов висновку про його виправдання за пред'явленим обвинуваченням [9].

Зі змісту судового рішення випливає, що органи досудового розслідування надали значну кількість фактичних даних на розгляд суду для визнання їх доказами. Проте, частина наданої правоохоронними органами інформації не сприйнята судом як належні докази, а інша не могла у своїй сукупності довести умисел вчинення кримінального правопорушення. Незважаючи на те, що стороною захисту було надано суду меншу кількість доказів, вони підтверджували факт фінансово-господарських відносин між вищезгаданими суб'єктами господарювання, чим спростовували факт вчинення обвинуваченим № 1 інкримінованого йому кримінального правопорушення. Отже, не так важлива кількість фактичних даних, яка подається суду на розгляд щодо визнання доказового іï значення, як їх зміст та належність отримання уповноваженими суб' єктами. 
Прикладом непрофесійності працівників правоохоронних органів є положення, відображені у вироку Святошинського районного суду міста Києва від 29.10.2019 за № 1-кп/759/23/19. Прокурор підтримував обвинувачення щодо особи (далі - обвинувачений № 2) за вчинення злочину, передбаченого частиною 5 статті 27, частиною 3 статті 212 КК України. Обвинувачення полягало в тому, що обвинувачений № 2 в період з 2011 по 2012 рік, перебуваючи в місті Києві, діючи як пособник, безпосередньо підшукав легально діючі суб'єкти господарювання (ТОВ «Адванс Групп», ТОВ «Смолінменеджмент-Ессе», ТОВ «Вальтравен», ТОВ «Видавничий дім «Престиж Альянс»), службові особи яких мали на меті ухилення від сплати податків, та шляхом надання засобів та знарядь для вчинення злочину, сприяв їм в ухиленні від сплати податків. Завдяки наданню певних послуг обвинуваченим № 2, директори суб' єктів господарювання завищували податковий кредит та занижували податок на додану вартість, а також податок на прибуток [10].

За вказаним кримінальним провадженням судом було допитано свідків та безпосередньо досліджено письмові докази, зокрема:

- стороною обвинувачення надано суду перший аркуш протоколу обшуку від 16.11.2012, а також зауваження до нього. Оскільки суду не було надано протокол обшуку від 16.11.2012 у повному обсязі, суд визнав його недійсним. Крім цього, судом саме слідчому надано дозвіл на проведення обшуку, однак у матеріалах кримінального провадження відсутнє доручення слідчого на проведення такої дії співробітнику оперативного підрозділу;

- протокол огляду від 17.11.2012, у якому зафіксовано огляд документів, що були вилучені під час проведення обшуку 16.11.2012 в нежитловому приміщенні, яке належало одному із згаданих у провадженні суб'єктів господарювання, а також документи інших наведених у справі суб'єктів господарювання фінансово-господарської діяльності. Оскільки протокол обшуку визнаний недійсним, то похідний від нього протокол огляду від 17.11.2012 та всі вищезазначені документи також є недопустимими доказами;

- висновки судових експертів про те, що відтиски печаток, відображені на документах вищезгаданих суб'єктів господарювання, відповідають інформації, яка міститься в кліше печаток цих же юридичних осіб, які були вилучені під час обшуку 16.11.2012. Також суд визнає їх недопустимими доказами, оскільки йому не було надано протоколи щодо вилучення в передбачений законом спосіб зазначених доказів у межах цього кримінального провадження;

- акти про результати документальної позапланової невиїзної перевірки зазначених суб'єктів господарювання. Суд визнав їх недопустимими доказами, оскільки вони базуються на аналізі документів, вилучених під час проведення обшуку від 16.11.2012.

- висновок експерта, яким визнано, що підписи в документах, вилучених під час обшуку 16.11.2012, виконані не директорами згаданих підприємств, а іншими особами. Суд також визнав їх недопустимими доказами, оскільки предметом дослідження експерта під час проведення зазначених експертиз були документи, вилучені протоколом обшуку від 16.11.2012, який визнаний судом недопустимим доказом; 
- протокол огляду від 25.08.2013, яким оглянуто носій інформації з каналів зв'язку мобільного телефону. Стороною обвинувачення ухвала суду на знаття інформації із каналів зв' язку не надана, тому доказ теж є недопустимим [10].

Оцінюючи показання свідків, допитаних у судовому засіданні, суд дійшов висновку, що вони також не підтвердили обставини, які б вказували на наявність у діях обвинуваченого № 2 пособництва в умисному ухиленні від сплати податків. Суд зауважив, що загалом обвинувачення грунтується на допущених порушеннях у сфері оподаткування іншими суб' єктами господарювання, отже, твердження сторони обвинувачення про доведеність вини обвинуваченого № 2, на думку суду, є припущеннями, оскільки жодним належним та допустимим доказом не підтверджено його вину у вчиненні умисних дій, які ставляться йому в провину [10].

3 цього приводу, на нашу думку, суд цілком виправдано застосував практику Свропейського суду з прав людини. У рішенні цього Суду «Інтерсплав проти України» (заява № 803/02) від 09.01.2007 визначено, що, коли державні органи володіють будь-якою інформацією про зловживання в системі відшкодування податків конкретною юридичною особою, то вони повинні спрямовувати передбачені законодавством заходи тільки до цієї юридичної особи з метою запобігання або усунення таких зловживань, а не розповсюджувати негативні наслідки на інших осіб за відсутності зловживання з їх боку [11].

Як вбачається зі змісту наведеного рішення суду, сторона обвинувачення не змогла довести винуватість обвинуваченого № 2 у вчиненні ним кримінального правопорушення, не було доведено суб'єктивну та об'єктивну сторони злочину i, як наслідок, суд виніс виправдувальний вирок. На наш погляд, сторона обвинувачення проявила себе непрофесійно, і фактично визнання судом одного протоколу обшуку недопустимим доказом звело нанівець усі інші наявні в матеріалах фактичні дані, адже, можливо, частина протоколу обшуку, яку не було надано суду, i ухвала суду на зняття інформації з каналів зв'язку все-таки була наявна, але в матеріалах іншого кримінального провадження, а прокурор не вжив відповідних заходів для представлення їх в суді. Водночас, належність виконання обов'язку доказування покладається як на слідчого, так і на прокурора, тому і відповідальність їх має бути спільною.

Розглянуте судове рішення є прикладом того, що: органам досудового розслідування в кожному кримінальному провадженні слід довести всі можливі обставини, що підлягають доказуванню, і на належному рівні, відповідно до законодавства України, відобразити та оформити фактичні дані, які будуть доводити винуватість чи невинуватість конкретної фізичної особи, у тому числі іï, як і представника юридичної особи; прокурорам потрібно вжити заходи задля забезпечення надання суду всіх доказів, перевіривши при тому належність оформлення матеріалів кримінального провадження. Звісно, такі дії уповноважених осіб не є вичерпними, але вони сприятимуть якісному доказуванню всіх обставин конкретного кримінального провадження у сфері оподаткування та ефективному підтриманню обвинувачення в суді.

Проаналізувавши 50 судових вироків за період від 2017 по 2020 роки (100%), 3 яких 16 вироків (32 \%) - виправдувальні, 1 вирок (2 \%) - у зв'язку із закінченням 
строків давності; 34 вироки (68 \%) - обвинувальні, з них 13 (26 \%) - за угодою про визнання винуватості, погоджуємося із О. О. Мельником, що до найбільш поширених способів учинення цього злочину належать: неподання документів, пов' язаних із обчисленням і сплатою податків, зборів, інших обов'язкових платежів; приховування та заниження об'єкта оподаткування [12, с. 123].

Висновки. 3 огляду на специфіку вчинення злочину, передбаченого статтею 212 КК України, та його склад, на наш погляд, вагоме значення має саме документальне підтвердження фактів умисного ухилення від сплати податків суб'єктами господарювання, адже показання свідків у судовому провадженні зазвичай не можуть відобразити всю суть правопорушення: у першу чергу, це полягає в тому, що такі злочини, з огляду на судові рішення, розслідують протягом тривалого часу і свідки не пам'ятають деяких фактів. Тому, як вбачається зі змісту досліджених судових рішень, показання свідків зазвичай відіграють опосередковану роль, тобто підтверджують факти, які встановлені актами перевірок чи іншими письмовими доказами.

Істотними обставинами, які підлягають доказуванню під час розслідування умисного ухилення від сплати податків, зборів (обов'язкових платежів), є: винуватість обвинуваченого у вчиненні цього злочину, форма вини і мета його вчинення; обставини, які підтверджують, що гроші, цінності та інше майно, що підлягають спеціальній конфіскації, одержані внаслідок вчинення кримінального правопорушення та/або є доходами від такого майна, або є предметом кримінального правопорушення; а також вид і розмір шкоди, завданої кримінальним правопорушенням. Водночас, не слід відносити до істотних обставин, що підлягають доказуванню, час, місце та мотив вчинення злочину, адже саме в цьому разі такі обставини суттево не впливають на повноту матеріалів кримінального провадження та їх розгляд по суті під час судового засідання.

\section{Використані джерела:}

1. Про зареестровані кримінальні правопорушення та результати їх досудового розслідування за статтею 212 Кримінального кодексу України за 2018, 2019, 2020 рр. Офіиційний сайm Oфіссу Генерального прокурора. URL : https://www.gp.gov.ua/ua/stat_n_st?dir_id=113 653\&libid=100820"=100820. (дата звернення: 08.02.2021).

2. Проект Закону України «Про Бюро економічної безпеки Украӥни» від 02.07.2020 p. №3087-д. URL: http:// w1.c1.rada.gov.ua/pls/ zweb2/webproc4_1?pf3511=69331. (дата звернення: 08.02.2021).

3. Кримінальний процесуальний кодекс Украӥни : Закон України від 13 квітня 2012 року, № 4651-VI.Редакція від: 14.01.2021. URL : https:/ / zakon.rada.gov.ua/laws/show/465117\#Техt. (дата звернення: 08.02.2021).

4. Пчеліна О. В. Обставини, що підлягають з'ясуванню під час розслідування кримінальних правопорушень, i їхне місце у структурі окремої криміналістичної методики. Прикарпатський юридичний вісник. 2020. № 2 (31). C. 187-190. DOI : https://doi.org/10.32837/ pyuv.v0i2(31).590.

5. Дрозд В. Г., Абламський С. Є. Дотримання процесуальної форми як критерій допустимості доказів у кримінальному про вадженні. Modern achievements of EU countries and Ukraine in the area of law: Collective monograph. Cuiavian University in Wloclawek, Zapo rizhzhia 
National University. Wloclawek - Riga: Izdevnieciba "Baltija Publishing". 2020. Part 1. P. 150-165. DOI : https:/ /doi.org/10.30525/978-9934-588-63-1.09.

6. Вирок Деснянського районного суду міста Чернігів від 09 грудня 2019 р., судова справа № 750/910/18. Єдиний державний реєстр судових рішень : [сайт]. URL : https:/ / reyestr. court.gov.ua/Review/86197379. (дата звернення: 08.02.2021).

7. Про деякі питання застосування законодавства про відповідальність за ухилення від сплати податків, зборів, інших обов'я зкових платежів: постанова Пленуму Верховного Суду України від 08 жовтня 2004 р. № 15. URL : https://zakon.rada. gov.ua/laws/ show/ v0015700-04\#Text. (дата звернення: 08.02.2021).

8. Падалка А. М. Доказування обставин у кримінальному провадженні про податковий злочин. The development of legal sciences: problems and solutions : Internat. sci.-pract. conf., April 27-28, Kaunas. Kaunas, 2018. C. 142-144.

9. Вирок Шевченківського районного суду м. Києва від 08 жовтня 2020 р., судова справа № 761/18549/15-к. Є2иний державний реєстр судових рішень : [сайт]. URL : https:// reyestr.court.gov.ua/Review/92106561. (дата звернення: 08.02.2021)

10. Вирок Святошинського районного суду м. Києва від 29 жовтня 2019 р., судова справа № 759/1319/16-к. Єоиний державний реєстр судових рішень : [сайт]. URL : https:// reyestr.court.gov.ua/Review/85250090. (дата звернення: 08.02.2021).

11. Справа «нтерсплав проти України» (заява № 803/02) : рішення Свропейського суду з прав людини від 09 січ. 2007 p. URL : https:/ / zakon.rada. gov.ua/laws/show/974_194 \#Tеxt. (дата звернення: 08.02.2021).

12. Мельник О. О. Основні способи ухилення від сплати податків, зборів та інших обов'язкових платежів. Боротьба з організованою злочнністю $і$ корупцією (пеорія і практика). 2014. № 2. C. 122-125.

\section{References:}

1. Pro zareiestrovani kryminalni pravoporushennia ta rezultaty yikh dosudovoho rozsliduvannia za statteiu 212 Kryminalnoho kodeksu Ukrainy za 2018, 2019, 2020 rr. Ofitsiinyi sait "Ofisu Heneralnoho prokurora", Official site "The Prosecutor General's Office". (2018-2020) N. p. URL: https://www.gp.gov.ua/ua/stat_n_st?dir_id=113653\&libid=100820. [in Ukrainian].

2. Proiekt Zakonu pro Biuro ekonomichnoi bezpeky Ukrainy: vid 02.07.2020 r. No. 3087d. (2020) N. p. URL : http://w1. c1.rada.gov.ua/pls/zweb2/webproc4_1?pf 3511=69331. [in Ukrainian].

3. Kryminalnyi protsesualnyi kodeks Ukrainy : Zakon Ukrainy vid 13 kvitnia 2012 roku, No. 4651-VI. Redaktsiia vid: 14.01.2021. (2021) URL : https://zakon.rada.gov.ua/laws/show/ 4651-17\#Text. [in Ukrainian].

4. Pchelina, O. V. (2020). Obstavyny, shcho pidliahaiut z'iasuvanniu pid chas rozsliduvannia kryminalnykh pravoporushen, i yikhnie mistse u strukturi okremoi kryminalistychnoi metodyky. Prykarpatskyi yurydychnyi visnyk - Prykarpattya Legal Bulletin, 2 (31), 187-190. DOI : https:// doi.org/10.32837/pyuv.v0i2(31).590/ [in Ukrainian].

5. Drozd, V. H., Ablamskyi, S. Ye. (2020) Dotrymannia protsesualnoi formy yak kryterii dopustymosti dokaziv u kryminalnomu prova dzhenni. Modern achievements of EU countries and Ukraine in the area of law: Collective monograph. Cuiavian University in Wloclawek, Zaporizhzhia National University. Wloclawek - Riga: Izdevnieciba "Baltija Publishing", part 1, 150-165. DOI : https://doi.org/10.30525/978-9934-588-63-1.09. [in English].

6. Vyrok Desnianskoho raionnoho sudu mista Chernihiv vid 09 hrudnia 2019 r., sudova sprava No. 750/910/18. Site "Yedynyi derzharnyi reiestr sudorykh rishen", Site "The only state register of court decisions". (2019) N. p. URL: https://reyestr.court.gov.ua/Review/86197379. [in Ukrainian]. 
7. Pro deiaki pytannia zastosuvannia zakonodavstva pro vidpovidalnist za ukhylennia vid splaty podatkiv, zboriv, inshykh obovia zkovykh platezhiv: postanova Plenumu Verkhovnoho Sudu Ukrainy vid 08 zhovtnia 2004 r. No. 15. (2004) N. p.URL : https://zakon.rada.gov.ua/ laws/show/v0015700-04\#Text. [in Ukrainian].

8. Padalka, A. M. (2018). Dokazuvannia obstavyn u kryminalnomu provadzhenni pro podatkovyi zlochyn. The development of legal sciences: problems and solutions : Internat. sci.-pract. conf., April 27-28, Kaunas. - Kaunas, 142-144. [in Lytva].

9. Vyrok Shevchenkivskoho raionnoho sudu $\mathrm{m}$. Kyieva vid 08 zhovtnia 2020 r., sudova sprava No. 761/18549/15-к. Site "Yedynyi derzhavnyi reiestr sudooykh rishen", Site "The only state register of court decisions". 92020) N. p. URL: https://reyestr.court.gov.ua/Review/92106561. [in Ukrainian].

10. Vyrok Sviatoshynskoho raionnoho sudu m. Kyieva vid 29 zhovtnia 2019 r., sudova sprava No. 759/1319/16-K. Site "Yedynyi derzhavnyi reiestr sudorykh rishen", Site "The only state register of court decisions". (2019) N. p. URL: https://reyestr.court.gov.ua/Review/85250090. [in Ukrainian].

11. Rishennia Yevropeiskoho sudu z prav liudy "Sprava "Intersplav proty Ukrainy" (zaia va No. 803/02)": 09 sich. 2007 r. (2007) N. p. URL: https:/ / zakon.rada.gov.ua/ laws/show/ 974 194\#Text. [in Ukrainian].

12. Melnyk, O. O. (2014). Osnovni sposoby ukhylennia vid splaty podatkiv, zboriv ta inshykh obov'iazkovykh platezhiv. Borotba z orhanizovanoiu zlochynnistiu i koruptsiieiu (teoriia i praktyka) - Fight against organized crime and corruption (theory and practice), 2, 122-125. [in Ukrainian].

Стаття надійшла до редколегії 10.02.2021

Моргун Н. С., кандидат юридических наук, профессор кафедры экономической безопасности и финансовых расследований Национальной академии внутренних дел (2. Киев, Украина)

Терещенко Ю. В., кандидат юоидических наук, доиент, профессор кафедры уголовного процесса Национальной академии внутренних дел (г. Киеъ, Украина)

\section{ОБСТОЯТЕЛЬСТВА, ПОДЛЕЖАЩИЕ ДОКАЗЫВАНИЮ ПРИ РАССЛЕДОВАНИИ УМЫШЛЕННОГО УКЛОНЕНИЯ ОТ УПЛАТЫ НАЛОГОВ, СБОРОВ (ОБЯЗАТЕЛЬНЫХ ПЛАТЕЖЕЙ)}

Статья посвящена определению обстоятельств, подлежащих доказыванию при расследовании умышленного уклонения от уплаты налогов, сборов (обязательных платежей) по материалам судебных решений.

Учитывая потребности практики расследования преступлений и рассмотрения дел в судебном производстве, а также статистические показатели деятельности правоохранительных органов Украины, приведен ряд факторов, как объективного, так и субъективного характера, влияющих на эффективность доказывания обстоятельств, определенных в статье 91 Уголовного процессуального кодекса Украины, при расследовании преступления, предусмотренного статьей 212 Уголовного кодекса Украины. Также предложены возможные направления их решения.

Выделено ряд обстоятельств, которые подлежат доказыванию, учитывая специфичность уголовного преступления.

Ключевые слова: уголовное производство, уклонение от уплаты налогов, сборов (обязательных платежей), обстоятельства, которые подлежат доказыванию, допустимость доказательств, судебное рассмотрение, приговор суда. 
Morhun N., Candidate of Juridical Sciences, Professor of the Department of Economic Security and Financial Investigations of the National Academy of Internal Affairs (Kyiv, Ukraine) Tereshchenko Yu., Candidate of Juridical Sciences, Associate Professor, Professor of the Department of Criminal Procedure of the National Academy of Internal Affairs (Kyiv, Ukraine)

\section{CIRCUMSTANCES TO BE PROVED IN THE INVESTIGATION OF DELIBERATE EVASION OF TAXES AND FEES (MANDATORY PAYMENTS)}

The article deals with the admissibility of evidence during the trial on taxes and fees (mandatory payments) deliberate evasion.

Taking into account the needs of the practice of crimes investigation and cases hearing in court proceedings, as well as statistical indicators of law enforcement agencies of Ukraine there are outlined a number of factors of both objective and subjective nature affecting the effectiveness of proving the circumstances, defined in Article 91 of the CPC of Ukraine, during the investigation of the crime provided by Article 212 of the Criminal Code of Ukraine, and possible ways to solve them are being suggested as well.

Based on the analysis of 50 court verdicts under Article 212 of the Criminal Code of Ukraine for the period from 2017 to 2020 it has been established that, according to the specifics of such a crime and its corpus delicti, the proper documentation of tax evasion by business entities is very important as evidence in court proceedings along with testimonies of witnesses usually playing an indirect role.

The article focuses attention to the European Court of Human Rights practice shared by the authors of the article that public authorities possessing any information about abuses in the tax refund system by a definite legal entity should direct statutory designed measures only to this legal entity in order to prevent or eliminate such abuses, and not to spread negative consequences to other persons in the absence of abuse on their part.

The authors concluded that the significant circumstances to be proved under Article 212 of the Criminal Code of Ukraine are: the guilt of the accused in committing a criminal offense, the form of guilt and the purpose of its commission; circumstances confirming that the money, valuables and other property subject to special confiscation are received as a result of the commission of a criminal offense and / or are income from such property, or are the subject of a criminal offense; as well as the type and amount of damage caused by a criminal offense.

Keywords: criminal proceedings, taxes and fees (mandatory payments) evasion, circumstances to be proved, admissibility of evidence, trial, court verdict. 